\title{
Total Polyphenol, Antioxidant and Antibacterial Activities of Black Mate Tea
}

\author{
Ferda Sari, Nihal Turkmen, Gokce Polat and Y. Sedat Velioglu* \\ Ankara University, Faculty of Engineering, Department of Food Engineering, 06110-Diskapi-Ankara-Turkey
}

Received September 18, 2006; Accepted March 23, 2007

\begin{abstract}
Black mate tea was extracted with different $50 \%$ solvents (acetone, N,N-dimethyl formamide (DMF), ethanol and methanol) for 2,8 and $18 \mathrm{~h}$. The extracts were screened for polyphenol content, antioxidant and antibacterial activities. Total polyphenol content of the extracts ranged from 97.01 to $119.28 \mathrm{mg}$ gallic acid equivalent (GAE)/g dry weight (dw) tea depending on the solvent used and extraction time applied. In general, methanol was the least efficient solvent for polyphenol extraction from black mate tea and the efficiency of the others was found to be similar. All extracts showed antioxidant activity by 2,2-diphenyl1-picryhydrazyl (DPPH) radical and reducing power. Different trend was observed for each method with respect to solvents used. The extracts possessed antibacterial activity depending on the solvent used and bacterium tested and the results sowed that black mate tea extracts had strong antimicrobial activity against selected bacteria, except for $E$. coli 0157 : H7. While $S$. aureus was found to be the most sensitive to all extracts, $E$. coli was the most resistant among bacteria tested.
\end{abstract}

Keywords: black mate tea, extraction, solvent, antioxidant, polyphenol, antibacterial

\section{Introduction}

Ilex paraguariensis is widely used for the preparation of the most popular tea-like beverage of South America (Filip et al., 2001). The commercial product made with it, named Mate or Yerba Mate is recognized worldwide for its nutritional and medicinal value being included in important national food codes and Pharmacopoeias (Anesini et al., 2006). Green mate is obtained after scorching, crushing, and drying leaves and stems, and can be stored for up to 1 year before commercialization, depending on the consumer's preference. Black mate $(\mathrm{BM})$ tea is obtained by the roasting of green mate at $160^{\circ} \mathrm{C}$ for approximately 12 min (Bastos et al. 2006). Mate tea was first used as a tonic and stimulating drink (Mazzafera, 1997). Nowadays, it is also considered functional food (Zuin et al., 2005) due to its some of the pharmalogical activities such as hepatoprotective, cholerectic, antioxidant and hypocholesteremic (Filip et al., 2001). Gugliucci and Stahl (1995) showed that water extracts of mate were capable of inhibiting the initiation and the propagation of low density lipoprotein (LDL) oxidation. Therefore, their use has been proposed as a dietary supplement for the prevention of the clinical expression of atherosclerosis and coronary heart disease (Carini et al., 1998). Mate tea is also used against mental and physical fatique (owing to the presence of xantines: caffeine and theobromine) (Anesini et al., 2006). This tea contains a significant amount of phenolic compounds, mainly caffeoylquinic acids, such as chlorogenic acid (Clouatre, 2004; Carini et al., 1998; Mazza-

\footnotetext{
* To whom correspondence should be addressed.
}

E-mail: velioglu@eng.ankara.edu.tr fera, 1997) and these compounds have many favourable effects on human health such as the lowering of human low-density lipoprotein and reduction of hearth disease and cancer (Baydar et al., 2004) due to their well-known abilities to scavenge free radicals, i.e. antioxidant power (Pinelo et al., 2004). The use of plants and herbs as antioxidants in processed foods is becoming of increasing importance in the food industry as an alternative to synthetic antioxidants (Proestos et al., 2006).

Microbial activity is a primary mode of deterioration of many foods and is often responsible for the loss of quality and safety. Currently, there is a growing interest to use natural antibacterial compounds for the preservation of foods (Jayaprakasha et al., 2003).The antimicrobial activity of plant extracts may reside in a variety of different components, including aldehyde and phenolic compounds (Dupont et al., 2006).

Although there have been some reports on antioxidant activity of BM tea (Bastos et al., 2006; Turkmen et al., 2005; Mello et al., 2005) little or no information is available on its antimicrobial activity. Therefore, the aim of this study was to clarify not only the antioxidant activity but also the antibacterial activity in BM tea extracts against different food-borne pathogens. In the present study, antioxidant activity of tea extracts was determined by using two methods based on different mechanism. One is DPPH radical scavenging assay most widely used for polyphenol from plant and the other is reducing power which was chosen due to the fact that iron-polyphenol complex was demonstrated to cause the inhibition of formation of oxygen radicals associated with many pathological conditions (Yoshino and Murakami, 1998) 
and also probably growth of some pathogen microorganisms (Chung et al., 1998).

\section{Materials and Methods}

Plant materials Brasilian originated BM tea (Ilex paraguarensis) samples were purchased from local market in Sydney-Australia. Tea samples were ground to pass a $710 \mu \mathrm{m}$ screen and stored at $+4^{\circ} \mathrm{C}$ before experiments.

Chemicals DMF (min 99.0\%), ethanol (min 99.8\%) and methanol (min $99.9 \%$ ) were either analytical or HPLC grade from Fluka (BioChemica-Fluka Cheme GmbH BuchsSwitzerland). Acetone (min 99.5\%) was from Aldrich (St. Louis, MO, USA). Folin-Ciocalteu's reagent was from Merck (Darmstadt-Germany). DPPH and TCA (trichloroacetic acid) were purchased from Sigma Chemical Co. (St. Louis, MO, USA). All other chemicals were analytical grade and from Merck.

Extraction of tea polyphenol Extracts from BM tea were prepared using aqueous solutions (50\%) of methanol, ethanol, DMF, acetone as solvents. The selection of these solvents was because our previous finding showed that $50 \%$ solvents were the most efficient for the polyphenol content and antioxidant activity of teas among various solvent systems included water and DMF, acetone, methanol, ethanol at various concentrations in water $(50,80$ and 100\%) (Turkmen et al., 2005). The ground BM tea sample $(0.2 \mathrm{~g})$ with $10 \mathrm{ml}$ of solvent was extracted at $23 \pm 2$ ${ }^{\circ} \mathrm{C}$ for different times (2, 8 and $18 \mathrm{~h}$ ) on horizontal shaker. The sample was filtered through Whatman No.1 filter paper to remove rough particles and then centrifuged (10 min, $10,000 \times \mathrm{g})$. The supernatant was stored at $-18^{\circ} \mathrm{C}$ until analyzed. Each solvent extraction was carried out in triplicate.

Determination of total polyphenol The amount of total polyphenol was determined using the Folin-Ciocalteu method (Obanda and Owuor, 1997). A calibration curve of gallic acid (range from 0.005 to $0.05 \mathrm{mg} / \mathrm{ml}$ ) was prepared and the results determined from regression equation of the calibration curve $\left(\mathrm{y}=62.94 \mathrm{x}-0.67, \mathrm{R}^{2}=0.99\right)$ were expressed as mg gallic acid equivalents (GAE)/g tea on dry weight basis. In this method, BM tea extract (1 ml) diluted 10-75 times with de-ionized water (to obtain absorbance in the range of the prepared calibration curve) was mixed with $1 \mathrm{ml}$ of 3 -fold-diluted Folin-Ciocalteu phenol reagent. $2 \mathrm{ml}$ of $35 \%$ sodium carbonate solution was added to the mixture, shaken thoroughly and diluted to $6 \mathrm{ml}$ by adding $2 \mathrm{ml}$ of water. The mixture was allowed to stand for $30 \mathrm{~min}$ and blue color formed was measured at $700 \mathrm{~nm}$ using a double beam spectrophotometer (Shimadzu UV-VIS 1601, Kyoto, Japan).

Antioxidant activity determination by $D P P H$ radical scavenging assay The antioxidant activity of BM tea samples was measured by using the DPPH assay (Katalinic et al., 2004; Atoui et al., 2005) with some minor modification. The extract $(80 \mu 1)$ diluted 15 -fold with distilled water was mixed with an aliquot of $1185 \mu 1$ of $6 \times 10^{-5} \mathrm{M}$ DPPH radical in methanol. Distilled water was used as a control instead of extract. The reaction mixture was vortex-mixed and let to stand at $25^{\circ} \mathrm{C}$ in the dark for 60 min. Absorbance at $517 \mathrm{~nm}$ was measured using a spectrophotometer using methanol as blank. Antioxidant activity was expressed as percentage inhibition (\% I) of the DPPH radical and was determined by the following equation (Yen and Duh, 1994):

$$
\% \text { Inhibition }=\frac{A b s_{\text {control }}-A b s_{\text {sample }}}{A b s_{\text {control }}} \times 100
$$

Antioxidant activity determination by reducing power Reducing power of BM tea extracts was determined according to the Yuan et al. (2005) with slight modifications. The extract $(0.5 \mathrm{ml})$ diluted 15 -fold with distilled water was mixed with $1.25 \mathrm{ml}$ of phosphate buffer (0.2 M, pH 6.6) and $1.25 \mathrm{ml}$ of potassium ferricyanide $(1 \%)$ and the mixture was incubated at $50^{\circ} \mathrm{C}$ in a water bath for $20 \mathrm{~min}$. Samples were then cooled and mixed with $1.25 \mathrm{ml}$ of $10 \%$ TCA. Afterwards, sample aliquot $(1.25 \mathrm{ml})$ was mixed with $1.25 \mathrm{ml}$ of distilled water and $0.25 \mathrm{ml}$ of $0.1 \%$ ferric chloride and then left to react at room temperature for 10 min. Sample absorbances (A) were read at $700 \mathrm{~nm}$. Increase in the absorbance of the reaction mixture indicated increase in the reducing power.

Antibacterial activity to determine antibacterial activity, Staphylococcus aureus, Listeria monocytogenes (A TCC 7644, Oxoid, UK), E. coli O157: H7, Hafnia alvei, Yersinia enterocolitica 0: 3 and Bacillus cereus were used as test bacteria. $Y$. enterocolitica 0:3 was grown in Tyriptic Soy Broth (Merck, Germany) at $30^{\circ} \mathrm{C}$ for $18-24 \mathrm{~h}$. The other bacteria were grown in the same medium at $37^{\circ} \mathrm{C}$ for $18-24 \mathrm{~h}$. Test microorganisms were obtained from the culture collections of Ankara University, Department of Food Engineering, Ankara, Turkey. Antibacterial activity was determined by the disc diffusion method (Bauer et al., 1966). A sterilize $6 \mathrm{~mm}$ diameter antibacterial susceptibility blank disc (Oxoid, Basinstoke, UK) was loaded with $200 \mu 1$ $(4 \mathrm{mg})$ of each extract of BM tea and left to dry in an open sterile Petri dish in a laminar air flow (Forma Scientific, Turkey). The test bacterium was transferred onto a $9 \mathrm{~cm}$ diameter Petri dish containing Nutrient Agar (Merck, Germany) using a sterile cotton swab and spread over the whole surface of the medium as a thin film. The inhibition of bacterial growth was evaluated by measuring the diameter of the transparent inhibition zone around each disc. Control disc was loaded with the same solvent and dried using the same method as the treated disc.

Statistical analysis Statistical analysis was conducted with SPSS for Windows (ver.10.1) and experimental results were expressed as means \pm standard errors of triplicate measurements. Analysis of variance was performed by one-way ANOVA procedure. Significant differences between means were determined by Duncan's multiple range test. Differences were considered significant at $p$ $<0.05$.

\section{Results and Discussion}

Polyphenol content The polyphenol content of BM tea extracts was examined and presented in Table 1. Total polyphenol content of the extracts ranged from 97.01 to $119.28 \mathrm{mg} \mathrm{GAE} / \mathrm{g}$ dw tea depending on the solvent 
Table 1. Total polyphenol content and antioxidant activity of BM tea aqueous extracts ${ }^{\mathrm{a}}$.

\begin{tabular}{|c|c|c|c|c|c|}
\hline \multirow[b]{2}{*}{ Parameter } & \multirow[b]{2}{*}{$\begin{array}{c}\text { Extr. } \\
\text { time (h) }\end{array}$} & \multicolumn{4}{|c|}{ Extraction Solvent } \\
\hline & & $50 \%$ Acetone & $50 \% D M F$ & $50 \%$ Ethanol & $50 \%$ Methanol \\
\hline & 2 & $117.62 \pm 2.25^{\mathrm{a} B}$ & $101.10 \pm 0.71^{\mathrm{aA}}$ & $98.58 \pm 1.72^{\mathrm{aA}}$ & $97.01 \pm 0.77^{\mathrm{a} A}$ \\
\hline Total polyphenol & 8 & $111.64 \pm 2.44^{\mathrm{a} \mathrm{B}}$ & $119.28 \pm 4.14^{\mathrm{bB}}$ & $111.17 \pm 1.76^{\mathrm{bB}}$ & $97.09 \pm 1.47^{\mathrm{aA}}$ \\
\hline (mg GAE/g dw tea) & 18 & $115.03 \pm 5.06^{\mathrm{a} \mathrm{B}}$ & $119.28 \pm 2.06^{\mathrm{b} \mathrm{B}}$ & $112.27 \pm 0.91^{\mathrm{bB}}$ & $99.76 \pm 0.34^{\mathrm{aA}}$ \\
\hline Antioxidant activity & 2 & $1.31 \pm 0.04^{\mathrm{aC}}$ & $1.26 \pm 0.01^{\mathrm{aC}}$ & $1.15 \pm 0.01^{\mathrm{a} \mathrm{B}}$ & $1.06 \pm 0.02^{\mathrm{aA}}$ \\
\hline Reducing power & 8 & $1.26 \pm 0.00^{\mathrm{aC}}$ & $1.27 \pm 0.01^{\mathrm{aC}}$ & $1.17 \pm 0.01^{\mathrm{a} \mathrm{B}}$ & $1.08 \pm 0.01^{\mathrm{aA}}$ \\
\hline & 18 & $1.21 \pm 0.07^{\mathrm{a} B C}$ & $1.28 \pm 0.01^{\mathrm{aC}}$ & $1.15 \pm 0.00^{\mathrm{a} A \mathrm{~B}}$ & $1.07 \pm 0.00^{\mathrm{aA}}$ \\
\hline & 2 & $93.00 \pm 0.49^{\mathrm{aA}}$ & $92.39 \pm 0.32^{\mathrm{aA}}$ & $92.69 \pm 0.12^{\mathrm{aA}}$ & $92.39 \pm 0.44^{\mathrm{aA}}$ \\
\hline \multirow{2}{*}{$\begin{array}{l}\text { Radical scavenging } \\
\text { activity (\% Inhibition) }\end{array}$} & 8 & $92.37 \pm 0.19^{\mathrm{aA}}$ & $92.26 \pm 0.22^{\mathrm{aA}}$ & $92.10 \pm 0.34^{\mathrm{aA}}$ & $92.00 \pm 0.17^{\mathrm{aA}}$ \\
\hline & 18 & $93.06 \pm 0.26^{\mathrm{aA}}$ & $92.19 \pm 0.37^{\mathrm{aA}}$ & $92.93 \pm 0.23^{\mathrm{aA}}$ & $92.54 \pm 0.31^{\mathrm{aA}}$ \\
\hline
\end{tabular}

${ }^{\mathrm{a}}$ : Data are expressed as means $\pm \mathrm{SE}$ of triplicate experiments. Means in a column $\left({ }^{\mathrm{a}, \mathrm{b}}\right.$ across extraction times) not having a common letter are different $(p<0.05)$.

Means in a row ( ${ }^{\mathrm{A}, \mathrm{B}, \mathrm{C}}$ across solvent types) not having a common letter are different $(p<0.05)$.

used and extraction time. Anesini et al., (2006) found that total polyphenol content of Yerba Mate was $6.89 \mathrm{~g} / 100 \mathrm{~g}$ dried plant material, respectively, which is lower than our results $(9.70-11.93 \mathrm{~g}$ GAE/100 g dw tea). The difference can be due to variation in the extraction procedure. In general, ethanol, DMF and acetone almost yielded similar polyphenol content at 2, 8 and 18 h of extraction but the lower amount of total polyphenol content was recorded in methanol extracts. As seen in Table 1, the increase in extraction time from $2 \mathrm{~h}$ to $8 \mathrm{~h}$ significantly increased polyphenol content of BM tea extracts when using DMF and ethanol as solvent. Lapornik et al. (2005) found that with increase in extraction time (from 1 up to $24 \mathrm{~h}$ ) total phenolics in methanol and ethanol extracts of grape strongly increased, which supports partly our results. On the other hand, with increasing time from 8 to $18 \mathrm{~h}$, polyphenol content of all extracts did not changed $(p<$ 0.05). The results showed that variation in polyphenol content with increasing extraction time varied depending on the solvent used, which was previously reported for Orthosiphon stamineus plant (Akowuah et al., 2005).

Antioxidant activity BM tea extracts possessed reducing power ranging between 1.06-1.31 (Table 1) much higher than the value of control sample $(0.123 \pm 0.12)$. Bravo et al. (2007) reported that mate infusions $(10 \mathrm{mg} / \mathrm{ml})$ had a reducing power slightly higher than black tea, but lower than green tea at the same concentrations, which supports partly our results. Regardless of extraction time, reducing power of the extracts was significantly affected by the extraction solvents with the following order from high to low: acetone $=\mathrm{DMF}>$ ethanol $>$ methanol. This result was also in consistent with the results of total polyphenol content. Negi et al. (2005) also noted differences in reducing power of various extracts of seabuckthorn seed. On the other hand, increase in extraction time (from 2 to $18 \mathrm{~h}$ ) did not have the effect on the reduc- ing power of the extracts (Table 1). Ilex paraguariensis contains significant level of caffeoylquinic acid isomers such as chlorogenic acid (Filip and Ferraro, 2003; Bixby et al., 2005; Anesini et al., 2006) which was shown to posses iron-reducing ability and protect $\mathrm{Fe}^{+2}$ ion from autooxidation completely (Yoshino and Murakami, 1998). Therefore it would be concluded that polyphenols, such as chlorogenic acid, in BM tea extracts contribute to their reducing powers.

The results of the free radical scavenging activity of BM tea extracts at the different extraction times were shown in Table 1 . The activities obtained for the extracts were found between 92.00-93.06\%, which indicates that tea extracts have a noticeable effect on scavenging free radical. Consistent with our results, Bixby et al. (2005) found that mate tea showed higher radical scavenging activity than red wines and green tea. Contrary to the results of reducing power, there was no statistically significant difference among solvent extracts with respect to radical scavenging activity. This can be due to the fact that different methods to measure antioxidant activity with various mechanisms may lead to different observations (Sun and Ho, 2005). However, the literature includes the studies reporting the effect of the extracting solvent on DPPH scavenging activity (CanadanovicBrunet et al., 2005; Negi et al., 2005; Yuan et al., 2005). The difference between the literature and our results can be due to variation in material used. Extraction time also did not affect the activity of the extracts, which is consistent with the results of reducing power. Phenolic compounds are known to reduce strongly DPPH radical due to the high reactivities of their functional groups, i.e. hydroxyl substituents (Heim et al., 2002; Rice-Evans et al., 1997). Additionally, Mello et al. (2005) reported that a good correlation was obtained between the radical scavenger capacity and total phenol content of mate tea ex- 
Table 2. Antibacterial activity of BM tea aqueous extracts.

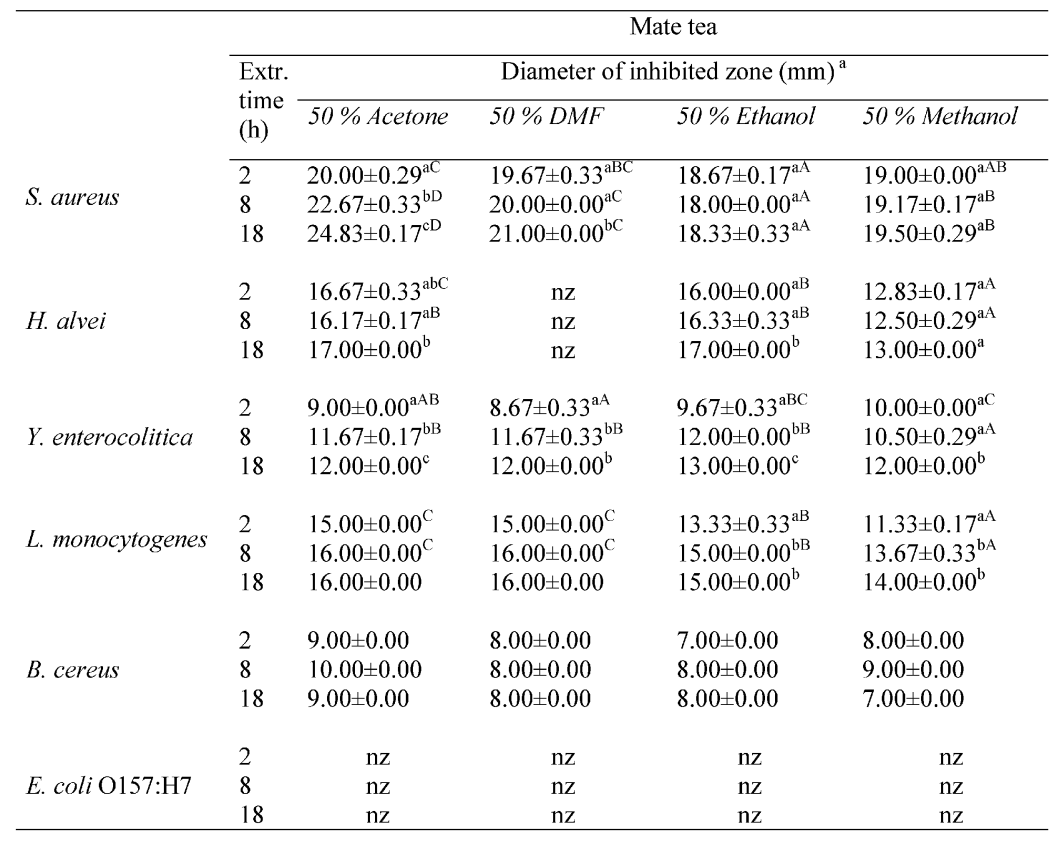

${ }^{\mathrm{a}}$ : Data are expressed as means $\pm \mathrm{SE}$ of triplicate experiments. Means in a column (a, b, c across extraction times) not having a common letter are different $(p<0.05)$.

Means in a row (A, B, C, D across solvent types) not having a common letter are different $(p<0.05)$.

nz: No inhibition zone detected.

tract. Therefore, polyphenols in BM tea extracts may be considered to be the main contributors to radical scavenging activity of BM tea extracts observed in our study.

Antibacterial activity The inhibitory effect of BM tea extracts on the growth of selected bacteria is presented in Table 2. Extraction solvents used as control had no inhibitory effects on the six bacteria tested. The extracts inhibited the growth to variable extents, except for $E$. coli, depending on the bacterium tested and solvent used. Acetone was found to be the most effective solvent against test bacteria but others were also effective although DMF extracts did not show any activity against H. alvei. While S. aureus was the least resistant to mate tea extracts $E$. coli was not inhibited by any of BM tea extracts. In general, increase in extraction time from 2 to $18 \mathrm{~h}$ significantly increased antibacterial activity of the extracts depending on the bacterium tested and the solvent used (Table 2).

With respect to the solvent used, the difference among antibacterial activity of the extracts was significant $(p<$ $0.05)$, depending on the test bacterium and extraction time. There is no data on the same materials in the literature. However, differences in antibacterial activity of various solvent extracts have been reported in previous studies with seabuckthorn seed (Negi et al., 2005) and grape seed (Baydar et al., 2004). A significant correlation was not observed between amounts of polyphenol and antibacterial activity of the extracts. However, antibacterial activity of plant extracts can be attributed to their individual phenolic compounds by previous studies
(Sakanaka et al., 2000; Jayaprakasha et al., 2003; Ozkan et al., 2004). On the other hand, an additional research on phenolic composition of each solvent extract is required for comprehensive assessment of individual compounds exhibiting antibacterial activity.

According to the results, it was surprising to find that DMF extracts of mate tea were not effective against $H$. alvei while other three extracts inhibited this bacterium. Determination of which compound necessary for inhibition of the bacterium is absent in DMF extracts will be also the subject of further work.

\section{Conclusions}

Polyphenol content of BM tea was influenced by solvents used and extraction time. All extracts showed remarkable antioxidant activity by DPPH radical and reducing power. Radical scavenging activity of the extracts was not affected by solvent used and extraction time while reducing power of the extracts was affected by only solvent. BM tea extracts exhibited antimicrobial activity against bacteria tested, except for $E$. coli. In medicine comprehensive studies on antibiotics have been carried out to enhance immune system in human. On the other hand, the effects of natural supplies such as plant extracts on pathogens have been investigated. The present study showed that BM tea could be a potential source for inhibitory substances for some food-borne pathogens.

Acknowledgements This work has been funded by research grant 
nr. 2005-0745-004-hpd from the Scientific Research Projects (BAP) of Ankara University, Turkey. Authors thank to Mrs. Seda Can (Sydney-Australia) for providing black mate tea.

\section{References}

Anesini, C., Ferraro, G. and Filip, R. (2006). Peroxidase-like activity of Ilex paraguariensis. Food Chem., 97, 459-464.

Atoui, A.K. Mansouri, A. Boskou, G. and Kefalas, P. (2005). Tea and herbal infusions: their antioxidant activity and phenolic profile. Food Chem., 89, 27-36.

Akowuah, G.A., Ismail, Z., Norhayati, I. and Sadikun, A. (2005). The effects of different extraction solvents of varying polarities on polyphenols of Orthosiphon stamineus and evaluation of the free radical-scavenging activity. Food Chem., 93, 311-317.

Bastos, D.H.M., Ishimoto, E.Y., Marques, M.O.M., Ferri, A.F. and Torres, E.A.F.S. (2006). Essential oil and antioxidant activity of green mate and mate tea (Ilex paraguariensis) infusions. J. Food Comp. Anal., 19, 538-543.

Bauer, A.W., Kirby, W.M.M., Sherries, J.C. and Turck, M. (1966). Antibiotic susceptibility testing by single disk method. Am. J. Clin. Pathol., 45, 493-496.

Baydar, N.G., Ozkan, G. and Sagdic, O. (2004). Total phenolic contents and antibacterial activities of grape (Vitis vinifera L.) extracts. Food Control, 15, 335-339.

Bixby, M., Spieler, L., Menini, T. and Gugliucci, A. (2005). Ilex paraguariensis extracts are potent inhibitors of nitrosative stress: A comparative study with green tea and wines using a protein nitration model and mammalian cell cytotoxicity. Life Sciences, 77, 345-358.

Bravo, L., Goya, L. and Lecumberri, E. (2007). LC/MC characterization of phenolic constituents of mate (Ilex paraguariensis, St. Hil.) and its antioxidant activity compared to commonly consumed beverages. Food Res. Int., 40, 393-405.

Canadanovic-Brunet, J.M., Djilas, S.M. and Cetkovic, G.S. (2005). Free-radical scavenging activity of wormwood (Artemisia absinthium) extracts. J. Sci. Food Agric., 85, 265-272.

Carini, M., Facino, R.M., Aldini, G., Calloni, M. and Colombo, L. (1998). Characterization of phenolic antioxidants from mate (Ilex paraguayensis) by liquid chromatography / mass spectrometry and liquid chromatography/tandem mass spectrometry. Rapid Commun. Mass Sp., 12, 1813-1819.

Chung, K.T., Lu, Z. and Chou, M.W. (1998). Mechanism of inhibition of tannic acid and related compounds on the growth of intestinal bacteria. Food Chem. Toxicol., 36, 1053-1060.

Clouatre, D. (2004). Green mate for energy, weight control and more. Total Health, 26, 52-54.

Dupont, S., Caffin, N., Bhandari, B., Dykes, G.A. (2006). In vitro antibacterial activity of Australian native herb extracts against food-related bacteria. Food Control, 17, 929-932.

Filip, R. and Ferraro, G.E. (2003). Researching on new species of "Mate": llex brevicuspis. Eur. J. Nutr., 42, 50-54.

Filip, R., Lopez, P., Giberti, G., Coussio, J. and Ferraro, G. (2001). Phenolic compounds in seven South American Ilex species. Fitoterapia, 72, 774-778.

Gugliacci, A. and Stahl, A.J.C. (1995). Low density lipoprotein oxidation is inhibited by extracts of Ilex paraguariensis. Biochem. Mol. Biol. Int., 35, 47-56.

Heim, K.E., Tagliaferro, A.R. and Bobilya, D.J. (2002). Flavonoid antioxidants: chemistry, metabolism and structure-activity re- lationships. J. Nutr. Biochem., 13, 572-584.

Jayaprakasha, G. K., Selvi, T. and Sakariah, K.K. (2003). Antibacterial and antioxidant activities of grape (Vitis vinifera) seed extracts. Food Res. Int., 36, 117-122.

Katalinic, V., Milos, M., Modun, D., Music, I. and Boban, M. (2004). Antioxidant effectiveness of selected wines in comparison with (+)-catechin. Food Chem., 80, 593-600.

Lapornik, B., Prosěk, M. and Wondra, A.G. (2005). Comparison of extracts prepared from plant by-products using different solvents and extraction time. J. Food Eng., 71, 214-222.

Mazzafera, P. (1997). Mate drinking: caffeine and phenolic acid intake. Food Chem., 60, 67-71.

Mello, L.D., Alves, A.A., Macedo, D.V. and Kubota, L.T. (2005). Peroxidase-based biosensor as a tool for a fast evaluation of antioxidant capacity of tea. Food Chem., 92, 515-519.

Negi, P.S., Chauhan, A.S., Sadia, G.A., Rohinishree, Y.S. and Ramteke, R.S. (2005). Antioxidant and antibacterial activities of various seabuckthorn (Hippophae rhamnoides L.) seed extracts. Food Chem., 92, 119-124.

Obanda, M. and Owuor, P.O. (1997). Flavanol composition and caffeine content of green leaf as quality potential indicators of Kenyan black teas. J. Sci. Food Agric., 74, 209-215.

Ozkan, G., Sagdic, O., Baydar, N.G. and Karamahmutoglu, Z. (2004). Antibacterial activities and total phenolic contents of grape pomace extracts. J. Sci. Food Agric, 84, 807-1811.

Pinelo, M., Rubilar, M., Sineiro, J. and Nunez, M.J. (2004). Extraction of antioxidant phenolics from almond hulls (Prunus amygdalus) and pine sawdust (Pinus pinaster). Food Chem., 85, 267-273.

Proestos, C., Boziaris, I.S., Nychas, G.J.E. and Komaitis, M. (2006). Analysis of flavonoids and phenolic acids in Greek aromatic plants: Investigations of their antioxidant capacity and antimicrobial activity. Food Chem., 95, 664-671.

Rice-Evans, C.A., Miller, N.J. and Paganga, G. (1997). Antioxidant properties of phenolic compounds. Trends Plant Sci., 2, 152-159.

Sakanaka, S., Juneja, L.R. and Taniguchi, M. (2000). Antimicrobial effects of green tea polyphenols on thermophilic sporeforming bacteria. J.Biosci. Bioeng., 90, 81-85.

Sun, T. and Ho, C. (2005). Antioxidant activities of buckwheat extracts. Food Chem., 90, 743-749.

Turkmen, N., Sari, F. and Velioglu, Y.S. (2005). Effects of extraction solvents on concentration and antioxidant activity of black and black mate tea polyphenols determined by ferrous tartrate and Folin-Ciocalteu methods. Food Chem., 99, 835-841.

Yen, G.C. and Duh, P.D. (1994). Scavenging effect of methanolic extracts of peanut hulls on free-radical and active oxygen species. J. Agric. Food Chem., 42, 629-632.

Yoshino, M. and Murakami, K. (1998). Interaction of iron with polyphenolic compounds: application to antioxidant characterization. Anal. Biochem., 257, 40-44.

Yuan, Y.V., Bone, D.E. and Carrington, M.F. (2005). Antioxidant activity of dulse (Palmira palmata) extract evaluated in vitro. Food Chem., 91, 485-494.

Zuin, V.G., Montero, L., Bauer, C. and Popp, P. (2005). Stir bar sorptive extraction and high performance liquid chromatography-fluorescence detection for the determination of polycyclic aromatic hydrocarbons in Mate teas. J. Chromatogr. A, 1091, 2-10. 